\title{
Detection of arboviruses of public health interest in free-living New World primates (Sapajus spp.; Alouatta caraya) captured in Mato Grosso do Sul, Brazil
}

\author{
Paulo Mira Batista ${ }^{[1],[2], ~ R e n a t o ~ A n d r e o t t i ~}{ }^{[3]}$, Paulo Silva de Almeida ${ }^{[1]}$, \\ Alisson Cordeiro Marques ${ }^{[4]}$, Sueli Guerreiro Rodrigues ${ }^{[5]}$, Jannifer Oliveira Chiang ${ }^{[5]}$ \\ and Pedro Fernando da Costa Vasconcelos ${ }^{[5]}$
}

[1]. Programa de Pós-Graduação em Doenças Infecciosas e Parasitárias, Universidade Federal de Mato Grosso do Sul, Campo Grande, MS. [2]. Coordenadoria Estadual de Vigilância Epidemiológica, Secretaria Estadual do Mato Grosso do Sul, Campo Grande, MS. [3]. Empresa Brasileira de Pesquisa Agropecuária (Gado de Corte), Campo Grande, MS. [4]. Secretaria Municipal de Saúde, Prefeitura Municipal de Ponta Porã, Ponta Porã, MS. [5]. Instituto Evandro Chagas, Secretaria de Vigilância Sanitária, Ministério da Saúde, Ananindeua, PA.

\begin{abstract}
Introduction: A sero-epidemiological survey was undertaken to detect the circulation of arboviruses in free-living non-human primates. Methods: Blood samples were obtained from 16 non-human primates (13 Sapajus spp. and three Alouatta caraya) that were captured using terrestrial traps and anesthetic darts in woodland regions in the municipalities of Campo Grande, Aquidauana, Jardim, Miranda and Corumbá in the State of Mato Grosso do Sul, Brazil. The samples were sent to the Instituto Evandro Chagas (IEC) in Ananindeua, Pará, Brazil, to detect antibodies against 19 species of arboviruses using a hemagglutination inhibition test (HI). Results: Of the 16 primates investigated in the present study, five (31.2\%) were serologically positive for an arbovirus. Of these five, two (12.5\%) exhibited antibodies to the Flavivirus genus, one (6.2\%) exhibited a monotypic reaction to Cacipacoré virus, one (6.2\%) was associated with Mayaro virus, and one (6.2\%) was positive for Oropouche virus. Conclusions: Based on the positive serology observed in the present study, it was possible to conclude that arboviruses circulate among free-living primates. The viruses in the areas studied might have been introduced by infected humans or by primates from endemic or enzootic areas. Studies of this nature, as well as efficient and continuous surveillance programs, are needed to monitor viral activities in endemic and enzootic regions.
\end{abstract}

Keywords: Non-human primates. Arboviral infection. Zoonoses.

\section{INTRODUCTION}

Arboviruses are transmitted and maintained in nature through wild cycles, in which several species of bloodsucking arthropods act as vectors and wild vertebrates act as reservoir hosts $^{1}$. The most commonly affected people are those who maintain close contact with wild environments where ecological niches of arbovirus exist ${ }^{2}$. In these environments, arboviruses can cause meningitis and diseases of the central nervous system, as seen for infections with St. Louis encephalitis virus (SLEV), Rocio virus (ROCV), eastern equine encephalitis virus (EEEV) and western equine encephalitis virus (WEEV) ${ }^{1}$.

Certain arboviruses appear regularly in urban areas, such as dengue virus (DENV) and Oropouche virus (OROV), or in peri-

Address to: Dr. Paulo Mira Batista. Coordenadoria Estadual de Vigilância Epidemiológica/SES/MS. Av. do Poeta, Bloco 7, Jardim Veraneio, Parque dos Poderes, 79031-902 Campo Grande, MS, Brasil.

Phone: 5567 3318-1682

e-mail:paulomirabatista@gmail.com

Received 10 September 2013

Accepted 25 November 2013 urban areas, such as Mayaro virus (MAYV) and yellow fever virus (YFV), causing epidemic febrile illnesses characterized by exanthematous and/or hemorrhagic fever ${ }^{1}$.

Arboviruses contain genomes made up of ribonucleic acid (RNA) that is either segmented or non-segmented ${ }^{3}$. These viruses are classified into five principal families according to their antigenic properties and physicochemical characteristics: Bunyaviridae, Flaviviridae, Reoviridae, Togaviridae and Rhabdoviridae ${ }^{1}$.

Arboviruses are considered to be emerging disease agents when they initially appear in a population or when their incidence or geographic distribution increases considerably ${ }^{3}$, as observed in a recent serological study of non-human primates (NHPs) in the municipality of Bonito, Mato Grosso do Sul, which detected antibodies to MAYV and OROV ${ }^{4}$. A number of factors can precipitate emerging disease, such as ecological changes due to economic development, agricultural or climatic abnormalities, demographic and behavioral changes, international traffic and wildlife trade, microbial adaptation or a collapse in public health control programs ${ }^{3}$.

Due to their arboreal and diurnal habits, non-human primates are more frequently infected by arboviruses than other terrestrial animals. They are infected when they feed in 
treetops, using the same feeding schedule as vectors ${ }^{5}$. Thus, they can act as important reservoirs in the cycle of several zoonoses. Furthermore, because they are part of a habitat with high biological diversity, they could be used for natural sentinel surveillance of emerging arboviruses, even when endangered by these diseases ${ }^{6}$.

Non-human primates can be used in biomedical research because they have anatomical, physiological, biochemical and behavioral similarities with humans ${ }^{7}$. Serological studies in wild animals have been limited. They have been performed through cross-sectional surveys, using several animals at a time, to detect the distribution of seropositivity and antibody titers to determine whether the host has been exposed to an antigen ${ }^{5}$.

Because they have genetic and physiological characteristics similar to those of humans, primates are susceptible to several common pathogens that can cross the boundaries of species through various transmission routes, particularly through vectors. Interaction between humans and wild primates living in tropical forests has increased due to ecotourism and the invasion of the forests, thereby increasing the likelihood of the transmission of pathogens ${ }^{6}$.

Arboviruses could potentially become an important public health problem in Brazil in the coming years. Monitoring programs should be able to detect these emerging viruses before they cause major outbreaks. Laboratory tests to confirm diagnosis are of great importance because these viruses cannot be easily distinguished clinically from other viral diseases, such as dengue ${ }^{8}$.

The aim of the present study was to conduct serological and virological tests to detect circulating arboviruses in non-human primates in the regions of Serra da Bodoquena and the Pantanal in Mato Grosso do Sul (Brazil) to provide information that could be used to define and improve prevention and control strategies for these important zoonoses.

\section{METHODS}

\section{The study site}

The wild animals used in the present study were captured from forests in the municipalities of Campo Grande (8), Aquidauana (1), Jardim (4), Miranda (2) and Corumbá (1) in the State of Mato Grosso do Sul (Figure 1). In these municipalities, there is a predominance of the cerrado ecosystem, which is characterized by short, sloping, twisted trees with thin trunks. The cerrado has well-defined climatic seasons: a rainy season in summer, from October to April, and a dry season in winter, which extends from June to August.

The City of Campo Grande, which is the capital of the State of Mato Grosso do Sul, is situated in the central region of the state, at approximately $532 \mathrm{~m}$ above sea level $\left(20^{\circ} 26^{\prime} 34^{\prime \prime} \mathrm{S}\right.$ and $\left.54^{\circ} 38^{\prime} 47^{\prime \prime} \mathrm{W}\right)$. It has an estimated area of $8,096.05 \mathrm{~km}^{2}$, and its population is approximately 765,000 inhabitants. The municipality of Aquidauana is located in the south of the Central West region of Brazil, in the Pantanal of Mato Grosso do Sul (micro-region - Aquidauana) in the region of the
Serra da Piraputanga and Maracajú $\left(20^{\circ} 28^{\prime} 15^{\prime \prime}\right.$ S and 55 47 $7^{\prime} 13^{\prime \prime}$ W). The municipality of Jardim is located in southwest Mato Grosso do Sul (21 $28^{\prime} 49^{\prime \prime} \mathrm{S}$ and $\left.56^{\circ} 08^{\prime} 17^{\prime \prime} \mathrm{W}\right)$. It has an area of $2,207.6 \mathrm{~km}^{2}$, with a humid sub-tropical climate and temperatures ranging from $15^{\circ} \mathrm{C}$ to $39^{\circ} \mathrm{C}$.

In the municipality of Miranda, animals were captured at a park hotel on Pantanal Park Road, Mato Grosso do Sul (20 $30^{\prime}$ $\mathrm{S}$ and $\left.56^{\circ} 15^{\prime} \mathrm{W}\right)$. In the City of Corumbá, non-human primates were captured in the Nhecolândia sub-region $\left(18^{\circ} 20^{\prime}-19^{\circ} 40^{\prime} \mathrm{S}\right.$ and $57^{\circ} 57^{\prime}-55^{\circ} 00^{\prime} \mathrm{W}$ ).

The Pantanal is a seasonal tropical wetland with an area of approximately $140,000 \mathrm{~km}^{2}$, and it is considered one of the largest freshwater ecosystems in the world ${ }^{9}$. The Brazilian Pantanal, which represents $85 \%$ of the total area of the Pantanal, is located in the States of Mato Grosso and Mato Grosso do Sul in the Central-West region of Brazil, and the parts of the Pantanal in these two states are known as the Pantanal North and South, respectively ${ }^{10}$. This region is ecologically classified into subregions according to vegetation, flooding and physiography ${ }^{11}$. The Nhecolândia sub-region, which is situated in the South Pantanal, comprises approximately one-fifth of the total area of the ecosystem, and it is characterized by hundreds of shallow lakes that exhibit different degrees of salinity, as well as coalescence of the system during floods ${ }^{12}$.

\section{Primates}

Blood samples from 16 free-living non-human primates were analyzed. Thirteen Sapajus spp. were captured using humane live terrestrial traps (Tomahawk) set in previously determined areas for easy viewing ${ }^{13}$. Three Alouatta caraya were captured with the aid of an anesthetic dart rifle $\mathrm{e}^{14}$. Of the animals captured, four $(25 \%)$ were female and $12(75 \%)$ were male, and $11(68.8 \%)$ were adults and five (31.2\%) were juveniles. The animals were anesthetized using a protocol based on the association of tiletamine hydrochloride and zolazepam hydrochloride ${ }^{15}$. The dosage, adjusted to the weight of the animal, was injected intramuscularly. All of the capture procedures were performed by a group of biologists and veterinarians, with the authorization of the Brazilian Institute of Environment and Renewable Natural Resources (Instituto Brasileiro do Meio Ambiente e dos Recursos Naturais Renováveis - IBAMA) under authorization number 21808-1.

Blood samples were collected, and aliquots of serum and whole blood were initially frozen in liquid nitrogen and then stored in a freezer at $-70^{\circ} \mathrm{C}$ until processing ${ }^{16}$. Biometric and clinical data were collected (data not shown), and microchip identification transponders were attached to the animals. After recovery from anesthesia, the animals were released.

\section{Serological tests}

The serum samples from the 16 animals were analyzed using the hemagglutination inhibition test (HI) and a panel of 19 different types of arbovirus distributed among the following genera: Alphavirus (WEEV, EEEV, MAYV and Mucambo virus), Flavivirus (YFV, Ilheus virus, SLEV, Cacipacoré virus, ROCV and Bussuquara virus), Orthobunyavirus (Guaroa, Maguari, Tacaiuma, Utinga, Belém, Caraparu, Catu and ORO virus) and Phlebovirus (Icoaraci virus). 


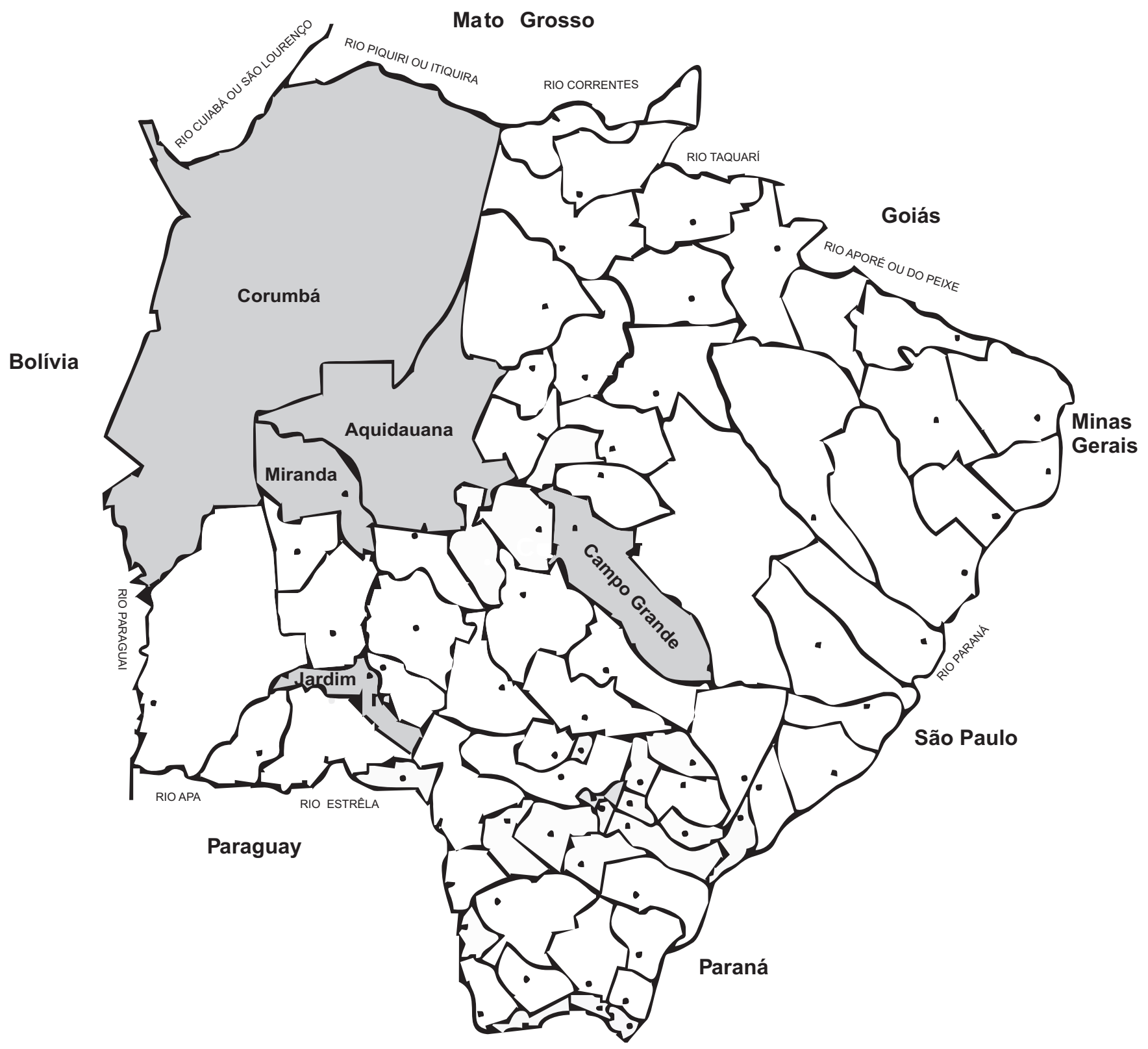

FIGURE 1 - Map of the State of Mato Grosso do Sul, Brazil, with the municipalities of Campo Grande, Aquidauana, Miranda, Jardim and Corumbá highlighted (study area).

The HI test used in the present study was standardized by the Section of Arbovirology and Hemorrhagic Fevers (SAARB) of the Instituto Evandro Chagas (IEC) following the protocol described by Clarke and Casals ${ }^{17}$, as adapted for microplates by Shope ${ }^{18}$.

The antigens used were prepared from the brains and/or serum of newborn infected mice using the sucrose-acetone and sorovirus extraction methods, respectively ${ }^{19}$. The serum samples were pre-treated with acetone to remove natural inhibitors, and they were adsorbed on goose erythrocytes (Anser cinereus) $)^{20}$ to remove non-specific agglutinins that might inhibit the agglutination of red blood cells, thereby avoiding false-positive results.

\section{Virological tests}

For virus isolation, newborn Swiss albino mice (Mus musculus) were inoculated intracerebrally with $0.02 \mathrm{~mL}$ of the serum and/or blood of the captured primates. The serum or blood samples were diluted 1:10 in buffered saline (PBS) containing antibiotics (100IU/ $\mathrm{mL}$ penicillin and $100 \mu \mathrm{g} / \mathrm{mL}$ streptomycin) and $0.4 \%$ bovine albumin. The animals were observed daily for 21 days, and any change was recorded on their identification cards. Concomitantly, a continuous culture of gut cells from Aedes albopictus Clone C6/36) was inoculated with the primate samples. The cultures were maintained in Leibovitz's modified culture medium with L-glutamine (L-15), supplemented with tryptose, non- 
essential amino acids, penicillin (100IU/mL) and streptomycin $(100 \mu \mathrm{g} / \mathrm{mL})$, using $5 \%$ fetal bovine serum (FBS) for the growth medium and $2 \%$ for the maintenance medium. The cultures were observed daily for 10 days with the aid of an inverted optical microscope to assess cytopathic effects (CPEs). Confirmation of viral replication in the cells was performed using the indirect fluorescent antibody test (IFAT) ${ }^{21}$ with polyclonal antibodies to Alphavirus and Flavivirus genera ${ }^{1}$.

\section{Statistical analysis}

Associations between variables of interest and arbovirus infection were quantified using prevalence ratios and their $95 \%$ confidence intervals, and the significance level was $5 \%$.

\section{RESULTS}

Of the 16 non-humans primates assessed in the present study, five $(31.2 \%)$ were serologically positive for antibodies to arboviruses (Table 1). Two primates exhibited antibodies to viruses belonging to the genus Flavivirus (titers from 1:80 to $1: 160$ ), one exhibited a monotypic reaction to Cacipacoré virus (titer 1:20), one exhibited a reaction to MAYV (titer 1:20), and one $(6.2 \%)$ exhibited a reaction to OROV (titer $1: 80)$ (Table 2 and Table 3).

There were no differences in the prevalence of infection by arboviruses according to sex, age or species.

\section{DISCUSSION}

The results found in the present study were similar to results previously reported for the municipality of Bonito (State of Mato Grosso do Sul), in which 17 (48.5\%) animals exhibited antibodies to arboviruses of the genus Alphavirus and Flavivirus, as well as monotypic reactions to Mayaro and Oropouche viruses. A number of samples also exhibited reactivity to more than one type of arbovirus ${ }^{4}$.

When non-human primates are assessed, the use of seroepidemiological surveys as an indicator of the circulation of arboviruses, as well as sentinel animals, is a feasible method for obtaining information concerning the presence of viruses in natural environments ${ }^{22}$ because these primates are arboreal and commonly diurnal species that are more frequently infected by arboviruses than other terrestrial animals.

In the present study, the HI test was used to detect the distributions of seropositive animals and antibody titers in non-human primates. The same diagnostic technique was used to detect arbovirus antibodies in spider monkeys (Ateles geoffroyi $)^{23}$. The HI test has often been used in serological surveys because it can detect antibodies over a long period after natural infection. It is considered a test of high sensitivity and low specificity compared to other serological tests, such as the immunoglobulin M (IgM) capture enzyme immunoassay (MAC-ELISA) $^{24}$. However, it is a more sensitive and accurate technique than methods that use large sample volumes, enabling savings in time and reagents. The HI test is an ideal method for detecting antibodies in wild animals captured in forests ${ }^{19}$.

In the present study, cross-reactivity was found between viruses belonging to the genus Flavivirus in two serum samples, precluding the identification of the infecting virus and the time of infection of the animals. With the HI test, it is common to observe the occurrence of cross-reaction between viruses belonging to this genus ${ }^{24}$. Positive results for the presence of antibodies to Flavivirus suggest that the host was exposed at some stage to one of the arboviruses studied and produced antibodies to combat it ${ }^{5}$.

The negative results found for viral isolation in the present study corroborate the data found in a previous study conducted

TABLE 1 - Antibodies against arboviruses in sera from 16 non-human primates (Sapajus spp.; Alouatta caraya) detected by the hemagglutination inhibition test, with the results grouped by sex, age and species.

\begin{tabular}{|c|c|c|c|c|}
\hline \multirow[b]{3}{*}{ Variables } & \multicolumn{3}{|c|}{ Hemagglutination inhibition } & \multirow[b]{3}{*}{ PR $(95 \% \mathrm{Cl})^{\mathrm{a}}$} \\
\hline & positive (\%) & negative (\%) & total (\%) & \\
\hline & $(n=5)$ & $(\mathrm{n}=11)$ & & \\
\hline \multicolumn{5}{|l|}{ Sex } \\
\hline male & $4(33.3)$ & $8(66.7)$ & $12(75.0)$ & 1 \\
\hline female & $1(25.0)$ & $3(75.0)$ & $4(25.0)$ & $1.33(0.20-8.71)$ \\
\hline \multicolumn{5}{|l|}{ Age } \\
\hline adult & $4(36.4)$ & $7(63.6)$ & $11(68.8)$ & 1 \\
\hline not adult & $1(20.0)$ & $4(80.0)$ & $5(31.2)$ & $1.82(0.27-12.40)$ \\
\hline \multicolumn{5}{|l|}{ Species } \\
\hline Alouatta caraya & $1(33.3)$ & $2(67.7)$ & $3(18.7)$ & 1 \\
\hline Sapajus spp. & $4(30.8)$ & $9(69.2)$ & $13(81.3)$ & $1.08(0.18-6.53)$ \\
\hline
\end{tabular}

PR $(95 \% \mathrm{Cl})$ : prevalence ratio and $95 \%$ confidence intervals. 
TABLE 2 - Arboviruses in samples from 16 non-human primates (Sapajus spp.; Alouatta caraya) according to the place of capture, Mato Grosso do Sul, Brazil, 2013.

\begin{tabular}{|c|c|c|c|c|c|c|c|c|c|c|}
\hline \multirow[b]{2}{*}{ Arbovirus } & \multicolumn{10}{|c|}{ Municipality } \\
\hline & $\mathrm{n}$ & $\%$ & $\mathrm{n}$ & $\%$ & $\mathrm{~N}$ & $\%$ & $\mathrm{n}$ & $\%$ & $\mathrm{n}$ & $\%$ \\
\hline Flavivirus & 1 & 12.5 & 1 & 25.0 & - & - & - & - & - & - \\
\hline Mayaro virus & - & - & 1 & 25.0 & - & - & - & - & - & - \\
\hline Oropouche virus & - & - & - & - & - & - & 1 & 50.0 & - & - \\
\hline Total & 1 & 12.5 & 2 & 50.0 & 1 & 100.0 & 1 & 50.0 & - & - \\
\hline
\end{tabular}

TABLE 3 - Antibody titers for arboviruses determined using the hemagglutination inhibition test, with the sex, age and the frequency of positive non-human primates (Sapajus spp.; Alouatta caraya) captured in the municipalities of Campo Grande, Jardim, Aquidauana, Miranda and Corumbá in the State of Mato Grosso do Sul, Brazil -2013.

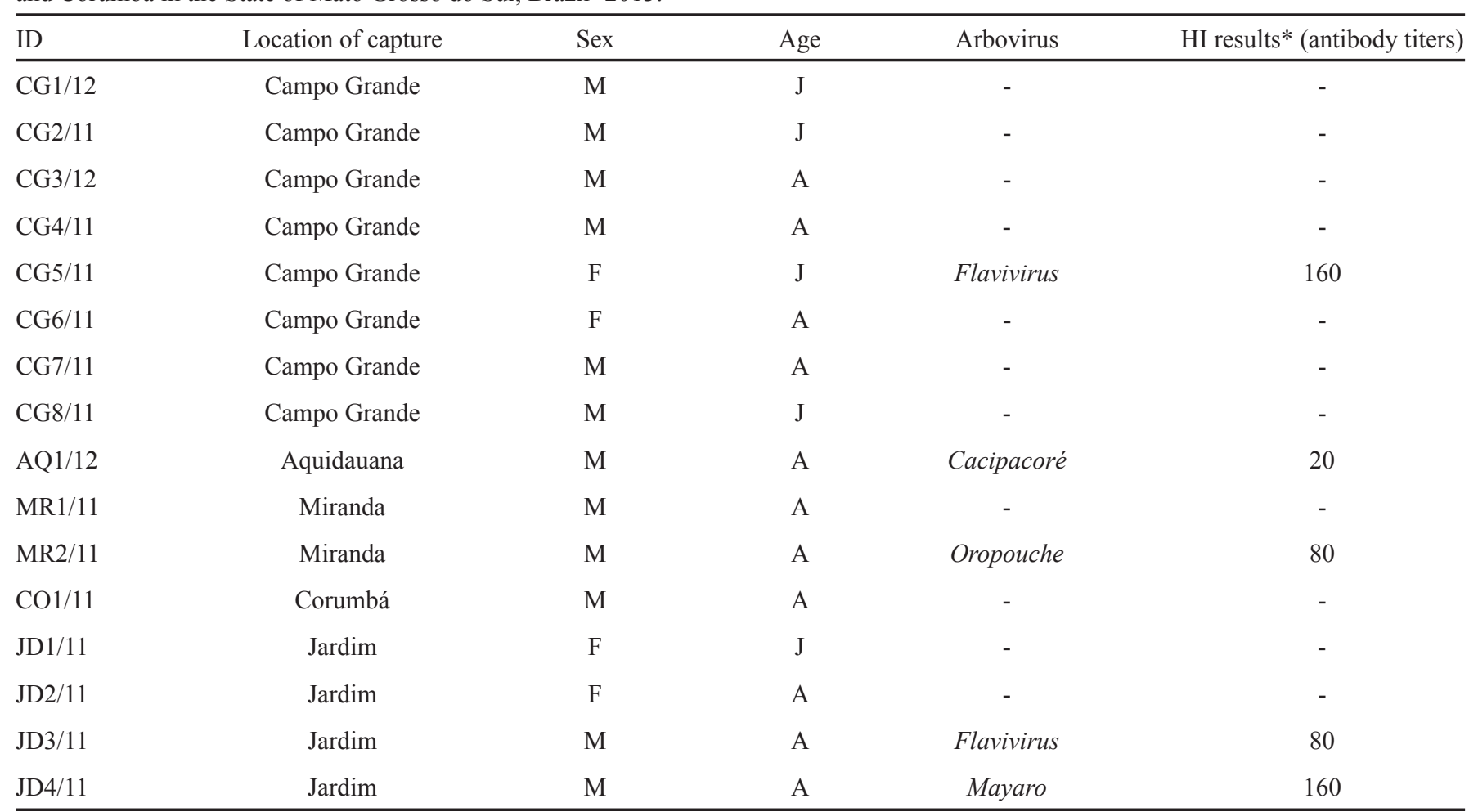

ID: identification of animal; HI: hemagglutination inhibition. * Test result: positive HI $\geq 1: 20$; M: male; F: female; J: juvenile; A: adult

in 35 non-human primates in a central region of Paraguay, which unsuccessfully attempted to isolate arboviruses in cell cultures of the Vero E6 strain ${ }^{25}$. Viral isolation from blood samples of animals and humans is considered to be a sensitive and economical method, and it is the gold standard for virological $\operatorname{diagnosis}^{24}$.

The detection of antibodies to Cacipacoré virus in a primate from the municipality of Aquidauana, together with a previous report of virus isolation on a farm in the State of Rondônia (northern Brazil, bordering Bolivia) ${ }^{26}$, suggests that the State of Mato Grosso do Sul could enable the spread of this arbovirus because the BR-262 highway connects the Southeast region of Brazil to the Bolivian border.

Similar to the results of the present study, antibody titers for MAYV were detected in 150 primate sentinels from French Guiana. A high prevalence of antibodies to arboviruses was observed in humans in the same study ${ }^{27}$. Antibodies to MAYV were also found in Callithrix argentata primates, using the HI 
test, during an investigation of outbreaks of Mayaro and yellow fever in Belterra, in the State of Pará, Brazil ${ }^{28}$. Similar results were also observed in a study of primates in the municipality of Bonito ${ }^{4}$.

MAYV can be transmitted by Aedes aegypti, which is the urban vector of dengue. Dengue is present in many Brazilian cities, including the municipalities surveyed, and there have been many cases of dengue in 2013, according to an epidemiological report of the State Department of Health ${ }^{29}$. MAYV might have been introduced into the urban areas near the study area by human travelers or by infected non-human primates that live in the forests around cities ${ }^{30}$. Mayaro virus was also detected in Venezuela, infecting the members of a family who exhibited clinical polyarthritis ${ }^{31}$.

The detection of antibodies to OROV in a primate sample from Passo da Lontra, in the municipality of Miranda, suggests the possible circulation of this virus in the region. Consequently, local people and tourists who maintain close contact with the natural environment could be susceptible to infection with $\mathrm{OROV}^{1}$. During a surveillance program of yellow fever and Oropouche in Minas Gerais, OROV was isolated in a liver sample from a primate of the genus Callithrix ${ }^{32}$, which is considered a new host for OROV in Brazil.

In contrast, the negative results for the primate captured in the City of Corumbá suggested that the virus did not circulate in that region or that the host was not exposed to any of the arboviruses studied. Another possible explanation for the negative result is the small number of animals captured ${ }^{5}$.

The positive results observed in the present study confirm the circulation of arboviruses in the wild, non-human primate populations of the State of Mato Grosso do Sul, Brazil. The State of Mato Grosso do Sul borders Paraguay and Bolivia, where arboviruses have been detected in a variety of primate and arthropod species. These regions exhibit favorable conditions for the occurrence of outbreaks caused by arboviruses. Therefore, much larger studies of this nature, as well as efficient and continuous epidemiological surveillance programs, are needed to monitor viral activities in endemic or enzootic areas. The results of these epidemiological studies could facilitate the discovery of diseases that affect primates and that can be transmitted to humans, thereby helping to prevent outbreaks in human populations $\mathrm{s}^{33}$.

\section{ACKNOWLEDGMENTS}

The authors would like to thank the Secretaria de Estado de Saúde de Mato Grosso do Sul for the logistical support, equipment and consumables necessary for the execution of field work.

\section{CONFLICT OF INTEREST}

The authors declare that there is no conflict of interest.

\section{FINANCIAL SUPPORT}

Fundação de Apoio ao Desenvolvimento do Ensino, Ciência e Tecnologia do Estado de Mato Grosso do Sul (FUNDECT), Secretaria de Estado de Saúde de Mato Grosso do Sul.

\section{REFERENCES}

1. Vasconcelos PFC, Travassos-da-Rosa APA, Pinheiro FP, Rodrigues SG, Travassos-da-Rosa ES. Arboviroses. In: Cimerman S, Cimerman B, editors. Medicina Tropical. São Paulo: Atheneu; 2003. p. 363-386.

2. Vasconcelos PFC, Travassos-da-Rosa APA, Pinheiro FP, Travassos-daRosa JFS. Arboviroses. In: Focaccia R, editor. Tratato de infectologia. São Paulo. Atheneu; 2005. p. 289-302.

3. Morse SS. Factors in the Emergence of Infectious Diseases. Emerg Infect Dis 1995; 1:7-15.

4. Batista PM, Andreotti R, Chiang JO, Ferreira MSF, Vasoncelos PFC. Seroepidemiological monitoring in sentinel animals and vectors as part of arbovirus surveillance in the State of Mato Grosso do Sul, Brazil. Rev Soc Bras Med Trop 2012; 45:168-173.

5. Thoisy B, Gardon J, Salas RA, Morvan J, Kazanji M. Mayaro vírus in wild mammals, French Guiana. Emerg Infect Dis 2003; 9:1326-1329.

6. Wolfe ND, Escalante AA, Karesh WB, Kilbourn A, Spielman A, Lal AA. Wild primate populations in emerging infectious disease research: the missing link? Emerg Infect Dis 1998; 4:149-158.

7. Torres LB, Araujo BHS, Castro PHG, Cabral FR, Marruaz KS, Araujo MS, et al. The use of new world primates for biomedical research: An overview of the last four decades. Am J Primatol 2010; 72:1055-1061.

8. Figueiredo LTM. Arboviroses emergentes no Brasil. Rev Soc Bras Med Trop 2007; 40:224-229.

9. Alho CJR. The Pantanal. In: Fraser LH, Keddy PA, editors. The world's largest wetlands: ecology and conservation. New York: Cambridge University Press; 2005. p. 203-271.

10. Alho CJR, Lacher TE, Gonçalves HC. Environmental degradation in the Pantanal ecosystem. Bioscience 1988; 38:164-171.

11. Silva JV, Abdon MM. Delimitação do Pantanal brasileiro e suas subregiões. Pesq Agrop Bras 1988; 33:1703-1711.

12. Adámoli I. O pantanal e suas relações fitogeográficas com os cerrados. Discussão sobre o conceito "Complexo Pantanal". In: Anais do $32^{\circ}$ Congresso Nacional de Botânica. Teresina, 1982. p. 109-119.

13. Aguiar LM, Ludwig G, Svoboda WK, Teixeira GM, Hilst CLS, Shiozawa MM, et al. Use of traps to capture Black and gold Howlers (Alouatta caraya) on the islands of the upper Paraná river, Southern Brazil. Am J Primatol 2007; 69:241-247.

14. Duque EF, Rotundo M. Field Methods for Capturing and Marking Azarai Night Monkeys. Int J Primatol 2003; 24:1113-1120.

15. Santos FGA, Salas ER, Marques JCB, Marques CC, Farias EMP. Cloridrato de tiletamina associado com cloridrato de zolazepam na tranquilização e anestesia de calitriquídeos (Mammalia, Primates). Arq Bras Med Vet e Zootec 1999; 51:539-545.

16. Ministério da Saúde. Manual de vigilância de epizootias em primatas não humanos. Secretaria de Vigilância em Saúde; Brasília; 2005.

17. Clarke DH, Casals J. Techniques for hemagglutination and hemagglutination\}inhibition with arthropod-borne viruses. Am J Trop Hyg 1958; 7: 561-573

18. Shope RE. The use of a micro hemagglutination-inhibition test to follow antibody response after arthropod-borne virus infection in a community of forest animals. In: Anais de Microbiologia, Rio de Janeiro, 1963. p. 167-171. 
19. Casals J, Brown M. Hemagglutination with arthropod-borne viruses. J Exp Med 1954; 99:429-449.

20. Travassos-da-Rosa APA, Travasos-da-Rosa ES, Travassos-da-Rosa JFS, Dégallier N, Vasconcelos PFC, Rodrigues SG, Cruz ACR. Os arbovírus no Brasil: generalidades, métodos e técnicas de estudo. Belém: Instituto Evandro Chagas/Fundação Nacional de Saúde; 1994.

21. Gubler DJ, Kuno G, Sather GE. Mosquito cell cultures and specific monoclonal antibodies in surveillance for dengue viruses. Am J Trop Med Hyg 1984; 33:158-165.

22. Svoboda WK. Vigilância de epizootia em primatas não humanos como instrumento de monitoramento de arboviroses e outras viroses de Interesse em Saúde Pública. [Doctors Thesis]. [Londrina]: Universidade Estadual de Londrina; 2007.

23. Tigor GH, Price HW. Antibody response in spider monkeys following single and double infections with group b arboviruses. Am J Epidem 1971; 94:386-396.

24. Vasconcelos PF. Yellow fever. Rev Soc Bras Med Trop 2003; 36:275-293.

25. Roig C, Rojas A, Guillén Y, Aria L, Mendonza L, Acosta ME, et al. Estudo de fiebre amarilla em primates em área de brote de los departamentos de San Pedro y Central de Paraguay. Mem Inst Investig Cienc Salud 2009; 7:40-45.

26. Batista WC, Tavares GSB, Vieira DS, Honda ER, Pereira SS, Tada MS. Notification of the first isolation of Cacipacore virus in a human in the State of Rondônia, Brazil. Rev Soc Bras Med Trop 2011; 44:528-530.
27. Talarmim A, Chandler LJ, Kaznji M, Thoisy B, Debon F, Lelarge J, et al. Mayaro virus fever in French Guiana: isolation, identification e seroprevalence. Am J Trop Med Hyg 1998; 59:452-456.

28. Vasconcelos PFC, Travassos-da-Rosa JFS, Travassos-da-Rosa APA, Dégallier N, Pinheiro FP, Sá-Filho GC. Epidemiologia das encefalites por arbovírus na Amazônia brasileira. Rev Inst Med Trop São Paulo 1991; $33: 465-476$

29. Secretaria de Estado de Saúde. Coordenadoria Estadual de Vigilância Epidemiológica. Boletim eletrônico epidemiológico nº 35 de 2013.

30. Tesh RB, Watts DMM, Russell KL, Damodaran C, Calampa C, Cabezas $\mathrm{C}$, et al. Mayaro virus disease: an emerging mosquito-borne zoonosis in tropical South America. Clin Inf Dis 1999; 28:67-73.

31. Torres JR, Russel KL, Vasques C, Barrera R, Tesh RB, Salas R, et al. Family cluster of Mayaro Fever, Venezuela. Emerg Infect Dis 2004; 10:1304-1306.

32. Nunes MRT, Martins LC, Rodrigues SG, Chiang JO, Azevedo RSS, Travassos-da-Rosa APA, et al. Oropouche vírus isolation, Southeast Brazil. Emerg Infect Dis 2005; 11:1610-1613.

33. Almeida MAB, Santos E, Cardoso JC, Fonseca DF, Torres MAN, Cardoso LL, et al. Vigilância da febre amarela e outras arboviroses através do monitoramento de primatas não humanos de vida livre no Rio Grande do Sul. Rev Soc Bras Med Trop 2008; 41 (suppl I): 173. 